\title{
Correction to: Pathology-supported genetic testing as a method for disability prevention in multiple sclerosis (MS). Part II. Insights from two MS cases
}

\author{
Susan J. van Rensburg ${ }^{1} \cdot$ Coenraad Hattingh ${ }^{1} \cdot$ Clint Johannes $^{2} \cdot$ Kelebogile E. Moremi $^{3} \cdot$ Armand V. Peeters $^{1}$. \\ Carel J. van Heerden ${ }^{4}$ - Rajiv T. Erasmus ${ }^{1}$. Annalise E. Zemlin ${ }^{3} \cdot$ Merlisa C. Kemp $^{5}$. Mariaan Jaftha ${ }^{5}$. Aye Aye Khine ${ }^{3}$. \\ Felix C.V. Potocnik ${ }^{6} \cdot$ Lindiwe Whati $^{7} \cdot$ Penelope Engel-Hills ${ }^{8} \cdot$ Ronald van Toorn $^{9} \cdot$ Maritha J. Kotze $^{3}$
}

Published online: 28 April 2021

(C) Springer Science+Business Media, LLC, part of Springer Nature 2021

\section{Correction: Metabolic Brain Disease.}

https://doi.org/10.1007/s11011-021-00712-9

The original version of this article was revised. The table below shows the incorrect and correct columns.

The online version of the original article can be found at https://doi.org/ 10.1007/s11011-021-00712-9

Susan J. van Rensburg

sjvr@sun.ac.za

1 Division of Chemical Pathology, Department of Pathology, Faculty of Medicine and Health Sciences, Stellenbosch University,

Cape Town, South Africa

2 Department of Internal Medicine, Faculty of Medicine and Health Sciences, Stellenbosch University, Tygerberg Academic Hospital, Cape Town, South Africa

3 Division of Chemical Pathology, Department of Pathology, Faculty of Medicine and Health Sciences, Stellenbosch University, National Health Laboratory Service (NHLS), Cape Town, South Africa

4 Central Analytical Facility (CAF), DNA Sequencing Unit, Stellenbosch University, Stellenbosch, South Africa
Department of Medical Imaging and Therapeutic Sciences, Faculty of Health and Wellness Sciences, Cape Peninsula University of Technology, Cape Town, South Africa

6 Department of Psychiatry and Mental Health, Faculty of Medicine and Health Sciences, Stellenbosch University, Cape Town, South Africa

7 Genetic Care Centre, Tygerberg Academic Hospital, Cape Town, South Africa

8 Faculty of Health and Wellness Sciences, Cape Peninsula University of Technology, Cape Town, South Africa

9 Department of Pediatrics and Child Health, Faculty of Medicine and Health Sciences, Stellenbosch University, Cape Town, South Africa 


\begin{tabular}{|c|c|c|}
\hline $\begin{array}{l}\text { Page No. } \\
\text { Section } \\
\text { Paragraph No. } \\
\text { Line No. }\end{array}$ & Incorrect & Correct \\
\hline $\begin{array}{l}\text { Page } 1 \\
\text { Author group } \\
\text { Line } 9\end{array}$ & Susan J. van Rensburg & Susan J. van Rensburg 0000-0002-2437-8978 \\
\hline $\begin{array}{l}\text { Page } 3 \\
\text { Genetic studies } \\
\text { Line } 13\end{array}$ & Realtime & Real-time \\
\hline $\begin{array}{l}\text { Page } 3 \\
\text { Case descriptions } \\
\text { Case } 1 \\
\text { Line } 1\end{array}$ & RR-MS & RRMS \\
\hline $\begin{array}{l}\text { Page } 6 \\
\text { MRI findings } \\
\text { Right hand column }\end{array}$ & $\begin{array}{l}\text { Figure } 1 \text { shows MRI Axial T2 FLAIR with multiple } \\
\text { hyperintense } \\
\text { periventricular white matter lesions of Case } 1 \\
\text { (1A) and } 2 \text { (1D) respectively, confirming diagnosis of MS. } \\
\text { MRI 3D T1 axial and T1 mid sagittal corpus callosum } \\
\text { thickness measurements were employed to evaluate brain } \\
\text { volumes. Preserved sulcal proportions, gyral volume (1B) } \\
\text { and corpus callosum thickness (1C) was noted in Case 1, } \\
15 \text { years after MS diagnosis. In contrast, case } 2 \text { exhibited } \\
\text { severe sulcal dilatation, reduction of gyral volume (1E) } \\
\text { and diffuse thinning of the corpus callosum (1F) supportive } \\
\text { of severe reduction in brain volume, } 13 \text { years after MS } \\
\text { diagnosis. At the time of the brain volume measurements, } \\
\text { Case } 1 \text { had an EDSS of } 2.0 \text {, while the EDSS of Case } 2 \text { was } \\
6.5 .1 \mathrm{C} \text { and } 1 \mathrm{~F} \text { show sagittal MRI images of the corpus } \\
\text { callosum thickness in Case } 1 \text { and Case } 2 \text { respectively. }\end{array}$ & $\begin{array}{l}\text { Figure } 1 \text { shows MRI Axial T2 FLAIR with multiple } \\
\text { hyperintense periventricular white matter lesions of Case 1 (a) } \\
\text { and } 2 \text { (d) respectively, confirming diagnosis of MS. MRI 3D } \\
\text { T1 axial and T1 mid sagittal corpus callosum thickness } \\
\text { measurements were employed to evaluate brain volumes. } \\
\text { Preserved sulcal proportions, gyral volume (b) and corpus } \\
\text { callosum thickness (c) was noted in Case } 1,15 \text { years after MS } \\
\text { diagnosis. In contrast, case } 2 \text { exhibited severe sulcal } \\
\text { dilatation, reduction of gyral volume (e) and diffuse thinning } \\
\text { of the corpus callosum (f) supportive of severe reduction in } \\
\text { brain volume, } 13 \text { years after MS diagnosis. At the time of the } \\
\text { brain volume measurements, Case } 1 \text { had an EDSS of } 2.0 \text {, } \\
\text { while the EDSS of Case } 2 \text { was } 6.5 \text {. Images c and f show } \\
\text { sagittal MRI's of the corpus callosum thickness in Case } 1 \text { and } \\
\text { Case } 2 \text { respectively. }\end{array}$ \\
\hline $\begin{array}{l}\text { Page } 9 \\
\text { Right hand column } \\
\text { Line } 89\end{array}$ & range. & range \\
\hline $\begin{array}{l}\text { Page } 10 \\
\text { Left hand column } \\
\text { Lines } 51\end{array}$ & levels & absorption \\
\hline $\begin{array}{l}\text { Page } 11 \\
\text { Declarations } \\
\text { Lines } 10-11\end{array}$ & $\begin{array}{l}\text { Publication fees for Open Access are supported by the } \\
\text { University of Stellenbosch, South Africa }\end{array}$ & Should be removed \\
\hline $\begin{array}{l}\text { Page } 11 \\
\text { Acknowledgements } \\
\text { Lines } 3-6\end{array}$ & $\begin{array}{l}\text { We acknowledge The South African BioDesign Initiative of the } \\
\text { Department of Science and Innovation, South Africa and } \\
\text { Winetech, Cape Town, South Africa for research funding }\end{array}$ & Should be removed \\
\hline
\end{tabular}

Publisher's note Springer Nature remains neutral with regard to jurisdictional claims in published maps and institutional affiliations. 